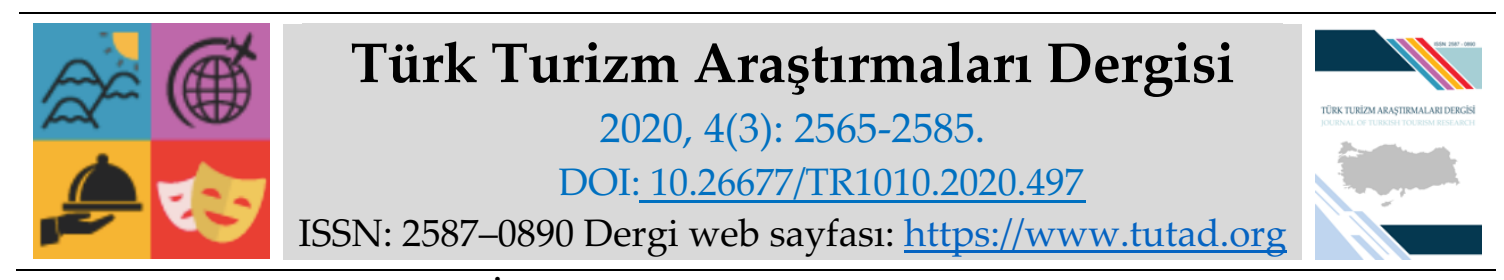

ARAŞTIRMA MAKALESI

\title{
Türkiye'deki Turizm Fakültelerinin ve Turizm Yüksekokullarının Stratejik Yönetim Anlayışı Bağlamında Misyon ve Vizyon Yaklaşımlarının Karşılaştırılması
}

Dr. Öğr. Üyesi Ercan YAVUZ, Ankara Hacı Bayram Veli Üniversitesi, Turizm Fakültesi, Ankara, e-posta: ercan.yavuz@hbv.edu.tr

ORCID: https://orcid.org/0000-0003-3696-4832

Öğr. Gör. Yusuf ORMANKIRAN, Hitit Üniversitesi, Sosyal Bilimler Meslek Yüksekokulu, Çorum, e-posta: yusuformankiran@hitit.edu.tr

ORCID: https://orcid.org/0000-0002-3321-3745

Öz

Araştırmada devlet ve vakıf üniversitelerinin lisans düzeyinde turizm eğitimi veren fakülte ve yüksekokulların stratejik planları içerisinde yer alan misyon ve vizyon bildirilerindeki ifadelerinin farklı ve ortak noktalarının tespit edilmesi amaçlanmaktadır. Bu amaç doğrultusunda araştırmaya; 41 turizm fakültesi ve 11 turizm yüksekokulu olmak üzere toplam 52 fakülte ve yüksekokul dahil edilmiş olup, turizm fakültelerinin ve turizm yüksekokulların misyon ve vizyon ifadeleri ile ilgili ayrıntılı bilgi elde edebilmek amaciyla analiz edilerek ifadelerin bildirildiği şekliyle betimlenmeye çalışılmıştır. Bu kapsamda turizm fakültelerinin ve turizm yüksekokullarının bildirmiş oldukları misyon ve vizyon ifadeleri nitel bir araştırma yönetimi olan doküman analizi tekniğinden yararlanılarak analiz edilmiştir. Araştırmada turizm fakülteleri ve turizm yüksekokulları misyon ifadelerini belirlerken turizm mesleki eğitime ve turizm teorik bilgisinin pratiğe dönüşümü vurgusu sıklıkla yapıldığı sonucuna ulaşılmıştır. Ayrıca turizm fakülteleri ve turizm yüksekokullarının stratejik planları kapsamında belirlemiş oldukları misyon ve vizyon ifadelerinin büyük oranda paralellik gösterdiği görülmüştür.

Anahtar Kelimeler: Stratejik Planlama, Vizyon, Misyon, Turizm Fakülteleri, Turizm Yüksekokulları.

Makale Gönderme Tarihi: 21.04.2020

Makale Kabul Tarihi: 05.07.2020

\section{Önerilen Atıf:}

Yavuz, E. ve Ormankıran, Y. (2020). Türkiye'deki Turizm Fakültelerinin ve Turizm Yüksekokullarının Stratejik Yönetim Anlayışı Bağlamında Misyon ve Vizyon Yaklaşımlarının Karşılaştırılması, Türk Turizm Araştırmaları Dergisi, 4(3): 2565-2585.

(C) 2020 Türk Turizm Araştırmaları Dergisi. 


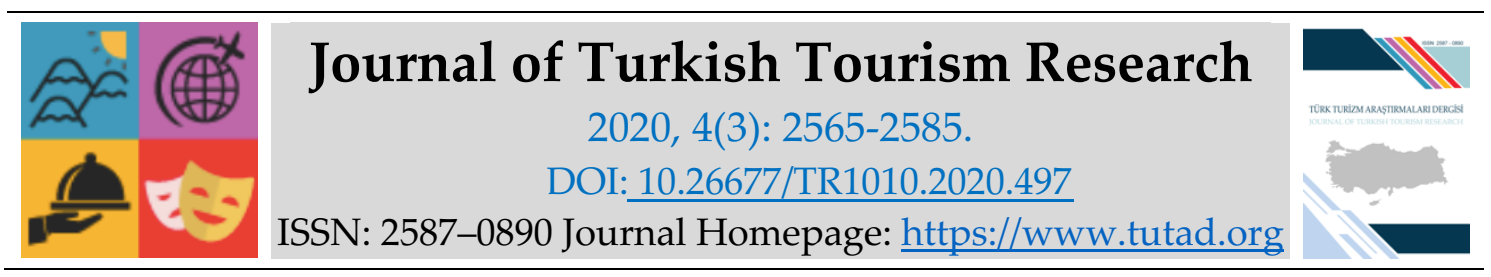

RESEARCH PAPER

\title{
In Turkey Tourism Faculties and Tourism Colleges Comparison of Mission and Vision Approaches in the Context of Strategic Management Approach
}

Assistant Prof. Dr. Ercan YAVUZ, Ankara Hacı Bayram Veli University, Faculty of Tourism, Ankara, e-mail: ercan.yavuz@hbv.edu.tr

ORCID: https://orcid.org/0000-0003-3696-4832

Öğr. Gör. Yusuf ORMANKIRAN, Hitit University, Vocational School of Social Sciences, Çorum, e-mail: yusuformankiran@hitit.edu.tr

ORCID: https://orcid.org/0000-0002-3321-3745

\begin{abstract}
In the research, it is aimed to determine the different and common points of the expressions in the mission and vision statements of the faculties and colleges that provide licensed tourism education of state and foundation universities in strategic planning. For this purpose, the research; A total of 52 faculties and colleges, including 41 tourism faculties and 11 tourism colleges, have been included, and have been analyzed in order to obtain detailed information about the mission and vision statements of tourism faculties and tourism colleges, and the descriptions have been tried to be described. In this context, the mission and vision statements reported by the tourism faculties and tourism colleges were analyzed using the document analysis technique, which is a qualitative research management. In the research, while emphasizing the mission statements of tourism faculties and schools of tourism, it was concluded that the emphasis was put on the vocational education of tourism and the transformation of tourism theoretical knowledge into practice. In addition, it has been observed that the mission and vision expressions determined by the tourism faculties and the schools of tourism within the strategic plans are largely parallel.
\end{abstract}

Keywords: Strategic Planning, Vision, Mission, Tourism Faculties, Tourism Colleges.

Received: 21.04 .2020

Accepted: 05.07.2020

\section{Suggested Citation:}

Yavuz, E. and Ormankıran, Y. (2020). In Turkey Tourism Faculties and Tourism Colleges Comparison of Mission and Vision Approaches in the Context of Strategic Management Approach, Journal of Turkish Tourism Research, 4(3): 2565-2585.

(C) 2020 Türk Turizm Araştırmaları Dergisi. 


\section{Gíriş}

Örgütler ve insanlar bir plan ve hedef kapsamında geleceğe daha güvenli bir şekilde yürüyebilmektedirler. Özellikle planların olası problem ve sorunları önceden tespitine olanak sağlaması örgütler için çok önemli olmakla birlikte eğitim kurumları içinde planlama bir zorunluluk haline geldiği söylenebilmektedir. Eğitim kurumları başta olmak üzere üniversitelerinde var oluş nedenleri, ihtiyaçları ve kendi alanlarındaki diğer rakiplerle gösterdiği mücadeleye bakıldığında diğer üniversitelerden çok farklı olmadığı görülmektedir (Çiçek vd., 2019: 546).

Örgütlere yol gösterici olan stratejik planlama ve stratejik planlamanın önemli unsurları arasında yer alan misyon ve vizyon ifadelerinin doğru tespit edilmesi, yalın ve anlaşılır olması örgütün hedeflerine ulaşmada oldukça önemli bir role sahiptir. Misyon, örgütün felsefesi ile değerlerini içeren ve diğer örgütlerden farklılaşmasını sağlayan ifadeler şeklinde tanımlanmaktadır. Vizyon ise, örgüt yöneticisinin zihninde tasarladığı ve örgütün gelecekteki konumu ile ilgili bir düşünce olarak tanımlanmaktadır. Birçok örgütte stratejik planları kapsamında misyon ve vizyon ifadeleri belirlendiği görülmektedir. Ancak bazı örgütlerde misyon ve vizyon cümleleri amacı dışına çıktığı dikkat çekmektedir. Buna rağmen örgütler hedef ve bu hedefler doğrultusundaki amaçları misyon ve vizyon ifadeleri içerisine yerleştirmektedir. Misyon ve vizyon ifadeleri ile örgütün üstlenmek istediği görevi, ulaşmak istediği güzergahla ve başarmak istediği amaçla ilgili çeşitli çıkarımlar yapmaya olanak sağlamaktadır.

Yükseköğretim Kalite Kurulu (YÖKAK) tarafından üniversitelerdeki kalitenin gelişmesi amacıyla yüksek öğretim kurumlarının dikkate alması gereken önemli bir unsur olan, misyon ve vizyon ifadelerinin belirlenip, yüksek öğretim kurumlarının stratejik planının içerisinde yer alması gerektiğini savunmaktadır. Bu bilgiler çerçevesinde yapılan araştırmada ise, devlet ve vakıf üniversitelerinin lisans düzeyinde turizm eğitimi veren fakülte ve yüksekokulların stratejik planları doğrultusunda belirlemiş oldukları misyon ve vizyon bildirilerinin içerik analizi yöntemi ile benzerlikleri ve farklılıkları ortaya koymak amaçlanmıştır.

\section{Strateji ve Stratejik Planlama Kavramı}

Strateji, Yunanlı General Strategos'un savunma ve taktik bilgilerinin üst düzeyde olmasından dolayı bu generalin adına atfen sevk etme ve yöneltme anlamlarının karşılığı olarak kullanılmaya başlanmıştır (Acar, 2007: 6). İşletmeye rekabet üstünlügü sağlamak, işletme ve çevresinin analiz edilerek işletmeye uyum sağlayacak amaçların belirlemek, işletmeye hedef göstermek, gerekli araçlar kullanılarak kaynakların yeniden düzenlenmesi ve faaliyetlerin planlanması süreci olarak tanımlanmaktadır (Dinçer, 2013:6). Bu bağlamda geleceği öngörmeye çalışan ve sürekli olarak değişen çevresel şartlara uyum sağlayan örgütler varlıklarını devam ettirirken uyum sağlayamayan örgütler ise yok olma durumuyla karşı karşıya kalmaktadırlar. Bu yüzden örgütler gelecekte de var olmak ve rakiplerine üstünlük sağlayarak belirlemiş oldukları amaçlara ulaşmak için geleceği bugünden tahmin etmeye çalışarak devam edebileceklerdir. Yukarıda belirtildiği gibi strateji kavramı değişimler karşısında örgütün dış çevreyle uyumuna odaklanmaktadır. Bu amaçla hareket eden örgütler, çabalarını sistemli ve stratejik bakışlı bir yaklaşımın altında yürütülebilecektir (Gültekin ve Mazı, 2016: 452).

Örgütlerin belirledikleri amaçlarına ulaşabilmesi için faaliyet gösterdikleri sektörde rakiplerinin faaliyetlerini sürekli olarak izlemek, rakiplerinin yapılan veya yapılabilecek muhtemel faaliyetlerini dikkate alması gerekmektedir. Muhtemel rakip faaliyetlerini ve kararlarını dikkate alarak örgütün varlık ve yeteneklerini kullanarak atılan her adım bir strateji olarak tanımlanmaktadır (Ülgen ve Mirze, 2014: 36). 
Stratejik planlama; örgüt yöneticilerinin uzun süreli hedeflerini, amaçlarını ve örgüt politikalarını belirlemede üstlenmiş oldukları rol ile eylemleri yönlendiren ve yön verme sırasında seçimleri içeren araçlar olarak tanımlanmaktadır. Bu kapsamda misyon ve vizyon ifadelerinin tüm faaliyetlere rehberlik ettiği söylenebilmektedir (Başpınar, 2020:471). Örgütlerin günlük faaliyetlerini yönlendiren ve anlam kazandıran bir araç olup; örgüt değerlerini, örgütün mevcut durumu ve örgüt çevresini değerlendirerek bu unsurları örgütün beklenilen gelecek durumu içi ilişkilendirilmesini içermektedir (Güner, 2006:91). Başka bir ifadeyle stratejik planlama, örgütlerin belirlemiş oldukları amaçlara ulaşmak maksadıyla oluşturdukları stratejik programlar kapsamında olup, bu programlar ile politikaların uygulanmasında gerekli görülen yöntemleri seçerek düzenlenmiş uzun vadeli bir süreç olarak tanımlamak mümkündür (Üzün, 2000:43).

Örgütlerin dünyada yaşanan hızlı değişimlerin dışında kalmak istememeleri, örgütün sürekliliğinin sağlamaları ve faaliyet alanında söz sahibi olmaları için stratejik planlama örgütler açısından vazgeçilmez bir faktör haline gelmiştir (Gültekin ve Mazı, 2016: 455). Stratejiler özellikleri gereği uzun vadeli planlar olduğu için stratejilerin uygulanması uzun zaman almaktadır. Rekabetçi yaklaşımlar yüzyıllar boyunca sürebileceğinden dolayı stratejik planlama bir stratejinin uygulanmasının ne kadar zaman alacağını uzun dönemli veya kısa dönemli ifadeleriyle açılamaktadır (Ginter vd., 2013:7). Stratejik planlama genel olarak; sertleşen rekabet ortamında rekabet üstünlüğü elde edebilmek ve örgütün anlayışını değiştirmeye yönelik bir yönetim tarzı oluşturmak için örgütün geleceğinin oluşturulması, değişimlere uyum sağlaması ve rakiplerine karşın fark yaratmasını içeren bir yönetim şekli olarak ifade edilebilir (Güner, 2006:93).

\section{Misyon ve Vizyon}

Misyon, uzun dönemde örgütlerin başarısını arttırmanın ve stratejik yönetimin etkili olmasının temel noktalarını oluşturan en önemli kavramlardan birisidir (Dinçer, 2013:9). Misyon, bir organizasyonun rekabet üstünlüğüne göre, rakiplerinin kendine özgü güçlü yanlarını ortaya çıkaran ve sunduğu teklifleri benzersiz kılmak amacıyla değerlerini tekrar vurgulamak olarak ifade edilir. En iyi misyon ifadeleri, çok sayıda örgütsel hedefin ve çok sayıdaki örgütsel hedefin stratejik arayışını yönlendirecek kadar genel, ancak örgütsel faaliyetlere ve kaynaklara odaklanacak ve öncelik verecek kadar spesifik olmalıdır. Vizyon ifadelerinin aksine, misyon ifadeleri normalde birkaç cümleden oluşmaktadır. Misyon ifadelerinin temelinde örgütün var oluş sebebi yatmaktadır (Bowen, 2018:3).

Misyon, örgütün iş felsefesini, sahip olacağı değerleri, diğer örgütlerden ne gibi farklılıkları olacağını kapsayan ifadeler bütünü olarak tanımlanmaktadır. Misyon ifadeleri bir örgütün var oluşunu anlatmakla birlikte örgütün diğer örgütlerden farklılaştırma çabası olarak ifade edilebilir. Misyon, örgütün daima en iyiye ve üstün başarılara yönelik şekillenmesiyle birlikte, örgüt çalışanlarının tamamıyla ilgili olarak söylenmelidir (Başpınar, 2020:471). Kısaca misyonu ifade edecek olursak, örgüleri farklı kılacak uzun dönemli bir görev ve ortak bir değer olarak ifade etmek mümkündür (Dinçer, 2013:10).

Misyon ifadesinde; örgütün faaliyet alanı, üretmiş olduğu mal veya hizmetlerin, üretim faaliyetinin çeşidinin ve faaliyette bulunduğu pazarların belirtilmesi önem arz etmektedir. Örgütün ürettiği mal ve hizmetler hedef kitleye uygun mu? Mal ve hizmetlerin üretiminde nasıl bir süreç izlenmektedir? Bu üretilen mal ve hizmetler hangi pazarlara sunulmaktadır? Bu sorulara verilen yanıtlar misyonda açıkça belirtilmesi gerekmektedir (Ülgen ve Mirze, 2014: 172). Misyon ifadesinin örgüt üyelerine bir hedef göstermesi ve anlam kazandırması amacıyla belirlenmektedir (Dinçer, 2013:10). 
Vizyon kavramı ise, toplumsal yaşamda her geçen gün daha sık kullanılmaya başlanmış ve buna bağlı olarak önemi de gittikçe artmakta ve yönetim biliminde de çok hızlı yaygınlaşmaktadır. Örgütler güçlü bir vizyona sahip oldukları takdirde yeni düşüncelere, teknolojiye ve yönetim anlayışlarına hızla adaptasyon sağlamaktadırlar. Vizyon sahibi yöneticiler, yönettiği örgütü topluma tanıtmaktadır. Çünkü vizyon, örgütü diğer örgütlerden farklılaştırmakta ve örgütün belirlemiş olduğu amaç ve hedeflerinin kamuoyuna yansıtılmasına aracılık görevi üstlenmektedir (Çetin, 2009:96). Vizyon, geleceğe yönelik olup; 5, 10, 15 veya 20 y1l içinde bir kuruluşun pazarda nerede konumlanmak istediğini açıklamaktadır. Vizyon, örgütün gelecekte rakiplerine göre nerede olmak istediği konusunda uzun vadeli en az bir büyük amacı içermeli ve ulaşmak istediği konum olarak ifade edilmelidir. Örgütsel vizyon normalde tek satırlık basit bir vizyon cümlesi ile ifade edilmektedir. Bu tür ifadeler, gerçek dünya sınırlandırmalarına göre biraz ideal veya normatif olabilen, ancak uyumlu bir çaba ile engelleri aşmak için işletmeye ilham veren stratejik bir başarı hedefi sunmaktadır. Bu kapsamda vizyon ifadeleri; örgütsel inovasyon, çalışanların bağlılığı ve motivasyonu; etkinlik ve rekabet alanındaki başarının temel itici güçleri şeklinde söylenebilmektedir (Bowen, 2018:1). Bir başka ifadeyle vizyon, işletmelerin gelecekte ne olabileceğine dair bir fikir, işletmenin gelecekteki durumu ve başarıları karşısında bir hayal, işletmenin muhtemel geleceğini gösteren bir fotoğraf olarak ifade edilebilir (Dinçer, 2013:6). Kısaca vizyon, işletmenin yöneticisinin zihninde bulunan, işletmenin gelecekteki konumu ve görünümü ile ilgili bir hayal olarak tanımlanmaktadır (Sökmen, 2016:307).

Vizyon üç önemli unsurdan oluşmaktadır. Bunlar: bir örgüte yol gösterebilecek bir yönetim felsefesi, gelecekte sahip olunmak istenen güçlü bir imaj ve geleceğe yönelik tahmin şeklinde sıralanmaktadır (Dinçer, 2013:7): Bunlardan birincisi; yönetim felsefesi, işletme vizyonunun başlangıç noktasını oluşturmaktadır. İşletmeler başarılı olabilmek ve devamlılığı sağlayabilmek için uygulayacakları politika ve faaliyetleri dayandırabilecekleri güçlü bir inanç sistemine ihtiyaç duymaktadır. Bu sistemi yönetim felsefesine dayandırarak uygulayabilmektedirler. İkincisi; güçlü bir imaj, işletmenin diğer bir önemli unsuru konumundadır. Böylelikle insanların belirli bir amaç üzerine odaklanmasını sağlamaktadır. Yönetim felsefesi vizyon ve misyonun arka planında yer alır iken imaj işletmenin görünen yüzü olarak karşımıza çıkmaktadır. Üçüncüsü ise, geleceğe yönelik tahmin; pazarın sahip olduğu teknolojik, demografik, politik, sosyal ve kültürel unsurlar çerçevesinde vizyon oluşturulmalıdır. Aksi takdirde, sağlam ve geçerli verilere oturmayan vizyon bir hayal ve fantezi olmaktan öteye gitmemektedir.

Vizyon bir örgütün paylaştığı ve sahip olduğu değerlerin bir sonucu olarak belirlenmektedir. Vizyon sadece tahmin yapmayı içermemekte, aynı zamanda karar almayı da kapsamaktadır. Örgütün gelecekte hangi konumda olmayı istediği ve amaçlanan hedefe ulaşmak için bu amacın hangi hedefler, hangi temeller üzerinde kurulacağı ve nasıl bir geleceğin oluşturulmak istendiği konularında örgüte yol gösteren bir ifade şeklinde söylenebilmektedir. Vizyonun yol gösterici olabilmesi için kolay kavranabilir bir şekilde tanımlamanın yapılması ve yalın bir dil kullanılması gerekmektedir. Örgüt üyelerinin tüm kademeleri tarafından benimsenmeli, büyük bir bütünün parçası olacakları için teşvik ve motive edici olmaları sağlanmalıdır (Kılıç, 2010: 89).

\section{Üniversitelerin Stratejik Yönetim Anlayışları}

Stratejik planlamalar genellikle uzun dönemli planlar olarak karşımıza çıkmaktadır. Eğitim alanında da stratejik planlamalar uzun dönemli olarak kendini göstermektedir. Bilim ve teknolojinin hızla gelişmesiyle beraber iletişimin artması, eğitimin fiziksel alanının gelişime uygun olarak düzenlenmesi, kalifiye ara eleman eksikliğinin artması, eğitim sisteminin sorgulanması ile geliştirilmesi gibi nedenlerden dolayı eğitim alanında da stratejik planlamanın yapılması zorunlu hale geldiği görülmüştür. Belirlenen amaçlar doğrultusunda eğitim sisteminin 
işlemesi, kurum yöneticilerinin stratejik planlarını etkin ve verimli bir şekilde hazırlayarak uygulamasına bağlıdır (Gültekin ve Mazı, 2016: 455). Üniversitelerde misyon, faaliyet alanını, üniversitenin değerlerini, var oluş nedenini ve kendilerini diğer üniversitelerden ayırabilmesi nedeniyle farkı yönlerini ortaya çıkarabilmek için izlemeleri gereken stratejileri gösteren yol haritası olarak ifade edilmektedir (Muslu, 2014: 155). Üniversite vizyonlarının belirlenmesinde; öğrenme modeli oluşturma, fırsat eşitliği sağlama, öğretim teknolojisi kullanma ve paydaşlara yönelik mesajlar içermesi gerektiği söylenmektedir (Başpınar, 2020:471).

Yükseköğretim Kurumu (YÖK) bünyesinde faaliyet gösteren Yükseköğretim Kalite Kurulu (YÖKAK), Türk Yükseköğretim Sistemi'ndeki iç ve dış kalite güvencesinin oluşturulması ve oluşturulan bu kalite güvencesinin etkin işleyişinin sağlanması amacıyla; yükseköğretim kurumlarının iç kalite güvencesi sistemlerinde referans alacakları Ulusal Kalite Güvencesi Sistemini geliştirmekte ve geliştirilen bu sistemin uygulanmasını desteklemektedir. Ayrıca yükseköğretim kurumları tarafından yıllık olarak hazırlanan Kurum İç Değerlendirme Raporları (KIDR) ile kurumların sahip olduğu iç kalite güvencesi sistemlerinin değerlendirilmesini sağlamaktadır. Bu kapsamda YÖKAK tarafından yürütülen diğer süreçler ise, kalite güvencesi konusunda yükseköğretim kurumlarının ihtiyaç duyduğu eğitim hizmetlerini organize etmek (YÖKAK, 2019a: 12), şeklinde tanımlanmakla birlikte kalite güvencesi uygulamalarının gelişebilmesi ve örnek uygulama niteliği kazanabilmesi için yükseköğretim kurumlarının göz önünde bulundurması gereken ilk unsur olarak "kurumun yerel, bölgesel, ulusal ve uluslararası eğilimlerini ve paydaş görüşlerini dikkate alan, çalışanlarınca bilinen/paylaşılan somut, gerçekçi misyon, vizyon, amaç ve hedefleri içinde barındıran bir stratejik planın ve kalite politikasının olması" (YÖKAK, 2019b: 85) ifadesi görülmektedir. Bu bağlamda, 20. yüzyıldan itibaren yükseköğretim alanında yaşanan değişim ile birlikte yükseköğretim alanında kalite güvencesi ilke ve standartları uygulanmaya başlanmış ve ülkeler kendi yükseköğretim sistemlerini değerlendirmeye alarak bu kalite güvence sistemi doğrultusunda gerekli geliştirmeleri yapmaktadırlar. Bu kapsamda ülkeler, yükseköğretim sistemlerinde çevreye uyumlu, yeniliklere açık, toplumun taleplerine karşı duyarlı, katılımcılığa önem veren, hedef ve öncelikleri önceden belirlenmiş, şeffaf ve etkin bir üniversite yapılanmasına yönelmişlerdir. Türkiye'deki yükseköğretim kurumlarında da bu gelişmeler kapsamında kalite standartlarının oluşturulması ve bu alanda uluslararası uyumluluğun sağlanabilmesi amacıyla çalışmalar yürütülmektedir (Özdem, 2011: 1870-1871).

İlgili literatür incelendiğinde bu konu ile ilgili birçok araştırma yapıldığı görülmektedir. Kılıç (2010), stratejik yönetim sürecinde değerler, vizyon ve misyon kavramları arasındaki ilişki adlı çalışmasında vizyon ve misyon kavramlarının birbiri yerine kullanıldığını belirtmiş, ancak kavramların farklı olduğunu ifade etmiştir. Çalışmada, misyon ve vizyon kavramlarına yöneticiler için yönetim kavramını fonksiyonel kılan örgütsel değerler ile aralarındaki bağlantı üzerinde durmuştur. Doğan (2007), stratejik yönetim alanında vizyon kavramının içeriği üzerine bir çalışma adlı araştırmasında Türkiye'deki firmaların yayınlamış oldukları vizyon ifadelerinin içerik analizi yöntemi ile incelenerek bu içeriklerin kapsamı ve bu içeriklerin kullanılmasının nedenleri üzerinde durmuştur. Firmaların mevcut durumu iyileştirme amaçlarına yönelik olarak gelecek 15 yıl sonrasında ortaya çıkabilecek değişimlere ilişkin ifadelerin olmadığını tespit etmiştir.

Eğitim kurumlarında misyon ve vizyon ile ilgili birçok araştırma yapıldığı görülmektedir. Boerema (2006), altı özel okul grubunun misyon ve vizyon ifadelerini içerik analizi kullanarak incelemiştir. Misyon ve vizyon ifadeleri yazar tarafından oluşturulan okulların özellikleri, amaç ve hedefleri, sundukları hizmetler, yerleştirildikleri ortam ve ebeveyn katılımı şeklinde içerik kategorisi kullanılarak analiz edilmiştir. Sonuç olarak; özel okullar arasında amaç ve hedeflerin boyutu açısından grup içi ve gruplar arası farklılıklar olduğu bulunmuştur. Çalık (2003), 
eğitimde stratejik planlama ve okulların stratejik planlama açısından nitel değerlendirilmesi adlı çalışmasında, okullarda yapılan stratejik planlama uygulamaların ne ölçüde etkili olduğunu araştırmıştır. Araştırmaya katılan okulların stratejik planlama konusunda başarısız olduğunu sonucuna ulaşırken, ilköğretim okullarının liselere göre stratejik planlamada daha fazla aşama kaydettiklerini ifade etmiştir. Morphew ve Hartley (2006), tarafından yapılan araştırmada kamuözel kolej ve üniversitelerin misyon ifadelerini incelemişlerdir. Araştırmanın sonucunda ise kamu-özel kolej ve üniversitelerinin misyon ifadelerini bildirirken farklı ifadeler kullanıldığını belirlemişlerdir. Firmin ve Gilson (2010), yapmış oldukları araştırmada kolej ve üniversitelerin misyon bildirilerini incelemişlerdir. Araştırma sonucunda misyon ifadelerinde eğitim, din, akademi, toplum ve yaşam gibi ifadelerin bulunduğu belirlemişlerdir.

Üniversitelere yönelik misyon ve vizyon ile ilgili araştırmalardan, Çiçek, Taş ve Yastıŏlu (2019); misyon, vizyon ve amaçlar bağlamında geleceğe bakış: Mehmet Akif Ersoy Üniversitesi stratejik plan çalışmaları örneği adlı araştırmasında Mehmet Akif Ersoy Üniversitesi'nin misyon ifadelerinde ulusallık, bölgesellik, çağdaşlık eğitim ve öğretim hizmetlerini geliştirmek gibi ifadelerin sıklıkla kullanıldığı tespit edilmiştir. James ve Huisman (2009), Galler'deki yükseköğretim kurumlarının misyon bildirilerinin bölgesel politikalara ve piyasa beklentilerine ne derece uyduğunu incelemişlerdir. Çalışmanın bulguları, yükseköğretim kurumlarının misyon bildirimlerinin bölgesel politikalara uymadığını ve pazar beklentilerini karşılamadığını göstermiştir. Özdem (2011), yükseköğretim kurumlarının stratejik planlarında yer alan vizyon ve misyon ifadelerinin analizi adlı çalışmada, üniversitelerin misyon bildirilerinde en çok evrensel nitelikte, yeterli ve yetkin bilgiye sahip olmak ifadesinin kullanıldığı tespit edilmişken, vizyon bildirilerinde ise en çok araştırma işlevine yönelik hizmetlerle ilgili ifadelere yer verildiği görülmüştür.

Literatür araştırması sonucunda misyon ve vizyon ile ilgili birçok araştırmaya rastlanmıştır. Araştırmanın konusuna uygun olarak eğitim kurumlarının misyon ve vizyon ifadelerinin analizleri yapıldığ çalışmalar üzerinde durulmuştur. Ancak yapılan çalışma sonucunda turizm fakülteleri ve turizm yüksekokullarına yapılan bir araştırmaya rastlanmamıştır. Araştırma, turizm lisans eğitimi veren kurumlar özelinde yapılması açısından önemli olduğu ifade edilebilmektedir. Misyon ve vizyon ifadeleri stratejik planların içeriği hakkında bilgi verdiğinden dolayı bu araştırmada da turizm fakülteleri ve turizm yüksekokullarının bildirmiş olduğu misyon ve vizyon ifadeleri analiz edilerek literatüre katkı sağlayacağı ve literatürdeki boşluğun giderileceğine inanılmaktadır.

\section{Araştırmanın Amacı}

Araştırmada devlet ve vakıf üniversitelerinin lisans düzeyinde turizm eğitimi veren fakülte ve yüksekokulların stratejik planları içerisinde yer alan misyon ve vizyon bildirilerindeki ifadelerinin farklı ve ortak noktalarının tespit edilmesi amaçlanmaktadır. Bu kapsamda ilgili ifadelerin hangi temalar altında yer aldığı belirlemeye çalışılmıştır.

\section{Araştırmanın Yöntemi}

Devlet ve vakıf üniversitelerin lisans düzeyinde eğitim veren turizm fakültelerinin ve yüksekokulların misyon ve vizyon ifadeleri ile ilgili ayrıntılı bilgi elde edebilmek amacıyla nitel bir araştırma yönetimi olan doküman analizi tekniğinden yararlanarak yapılmıştır. Araştırmanın evrenini, YÖK Atlas veri tabanında yer alan devlet ve vakıf üniversitelerinin turizm fakülteleri ve turizm yüksekokulları oluşturmaktadır. Vakıf üniversitelerinin turizm ile ilgili bölümleri farklı fakülte ve yüksekokullar altında açtığı tespit edilmiştir. Bu kapsamda vakıf üniversiteleri 
içerisinde toplam 1 turizm fakültesi 1'de turizm yüksekokuluna ulaşılmıştır. Araştırmanın örneklemi ise devlet ve vakıf üniversitelerinin turizm fakülteleri ve turizm yüksekokullarının misyon ve vizyon bildirilerini yayımlayan üniversitelerden oluşmaktadır. Bu kapsamda 40 devlet 1 vakıf olmak üzere toplam 41 turizm fakültesi bulunmaktadır. Ayrıca 10 devlet 1 vakıf olmak üzere toplam 11 turizm yüksekokul bulunmaktadır. Araştırmaya toplam 52 fakülte ve yüksekokul dahil edilmiştir.

\section{Veri Toplama}

Araştırmada devlet ve vakıf üniversitelerinin lisans düzeyinde turizm eğitimi veren toplam 52 fakülte ve yüksekokulun kurumsal web sitelerindeki misyon ve vizyon bildirileri nitel araştırma yöntemlerinden olan doküman analizi tekniği ile incelenmiştir.

\section{BULGULAR}

Araştırmada üniversitelerin stratejik planları kapsamında yer alan misyon ve vizyon ifadeleri ile ilgili bulgulara yer verilmiştir. Misyon ve vizyon ifadeleri alt temalara göre incelenmiştir. Özdem (2011)'in yükseköğretim kurumlarının stratejik planlarında yer alan vizyon ve misyon ifadelerinin analizi adlı çalışmasında yer alan temalar dikkate alınmıştır. Araştırma sırasında turizm fakülteleri ve turizm yüksekokullarına uygun temalar kullanırken, uygun olmayan temalar araştırma kapsamının dışında tutulmuştur. Ayrıca araştırma sırasında ilgili temalar çalışmaya eklenmiştir.

Tablo 1. Turizm Fakülteleri ve Turizm Yüksekokullarının Stratejik Planlarında Yer Alan Misyon İfadelerinin Ana Temalara Göre Dağılımı

\begin{tabular}{|c|c|c|c|c|c|c|c|c|c|c|c|}
\hline \multirow{3}{*}{$\begin{array}{l}\text { Misyon İfadelerinde } \\
\text { Alan Ana Temalar }\end{array}$} & \multirow{3}{*}{ e Yer } & \multicolumn{4}{|c|}{ Turizm Fakülteleri } & \multicolumn{4}{|c|}{ Turizm Yüksekokulu } & \multicolumn{2}{|c|}{ Toplam } \\
\hline & & \multicolumn{2}{|c|}{ Devlet } & \multicolumn{2}{|c|}{ Vakıf } & \multicolumn{2}{|c|}{ Devlet } & \multicolumn{2}{|c|}{ Vakıf } & \multirow[b]{2}{*}{$f$} & \multirow[b]{2}{*}{$\%$} \\
\hline & & $\mathrm{f}$ & $\%$ & $\mathrm{f}$ & $\%$ & $\mathrm{f}$ & $\%$ & $f$ & $\%$ & & \\
\hline $\begin{array}{l}\text { Eğitim Öğretim İşlevi } \\
\text { Teması }\end{array}$ & Ana & 42 & 22,11 & 1 & 20 & 7 & 21,21 & - & - & 50 & 21,55 \\
\hline $\begin{array}{l}\text { Araştırma İşlevi } \\
\text { Teması }\end{array}$ & Ana & 53 & 27,89 & 2 & 40 & 9 & 27,27 & 2 & 50 & 66 & 28,44 \\
\hline $\begin{array}{l}\text { Toplumsal İşlev } \\
\text { Teması }\end{array}$ & Ana & 26 & 13,68 & - & - & 5 & 15,16 & - & - & 31 & 13,36 \\
\hline $\begin{array}{l}\text { İnsan Kaynakları } \\
\text { Ana Teması }\end{array}$ & İşlevi & 69 & 36,32 & 2 & 40 & 12 & 36,36 & 2 & 50 & 85 & 36,63 \\
\hline Toplam & & 190 & 100 & 5 & 100 & 33 & 100 & 4 & 100 & 232 & 100 \\
\hline
\end{tabular}


Misyon ile ilgili ifadeler için Tablo 1'e baktığımızda turizm fakülte ve yüksekokulların stratejik planlarında yer alan misyon ifadelerinin ana temalarına göre dağılımı yer almaktadır. Bu bağlamda 52 fakülte ve yüksekokulların misyon ifadelerinden toplam 232 farklı mesaj tespit edilmiştir. Ana temalar arasında en çok vurgulanan tema \% 36,63 ile insan kaynakları işlevi ana teması olmuştur. En az sıklıkla vurgulanan tema ise \%13,36 ile toplumsal işlevi ana teması olmaktadır. Turizm fakülteleri ve turizm yüksekokulları boyutu ile bakıldığında da ilk sırada insan kaynakları işlevi yer aldığı görülmektedir. Bu sonuca göre, fakültelerin ve yüksekokulların öncelikli görevi iş gücü talebine karşıllk verebilmesi olduğu görülmektedir. Böylelikle sektörün talep etmiş̧ olduğu iş gücünü karşılayarak turizm sektörünün gelişimine katkıda bulunmayı bir görev edindiği söylenebilir.

Tablo 2'de eğitim öğretim işlevine yönelik alt temasında olan misyon ifadelerinin dağılımı yer almaktadır. Tablo incelendiğinde eğitim öğretim işlevine yönelik ifadenin alt temasında $\% 28,00$ ile turizm mesleki eğitim sunan misyon ifadesinin yer aldığı görülmektedir. Ardından \%12,00 ile turizm teorik bilgisini pratiğe dönüştürme imkanı sunan misyon ifadesi bulunmaktadır. Bu durumun fakülte ve yüksekokul boyutunda da değişmediği görülmektedir. En az sıklıkla yer alan ifadeler ise, bilgi toplumunun oluşmasına katkı sağlamak, Türkiye Cumhuriyeti'nin temel ilkelerine ve bilimin evrensel değerlerine uygun bir eğitim anlayışı, eğitim danışmanlığı yapmak ve öğrenci odaklılık ifadeleri yer almaktadır.

Tablo 2'de görüldüğü üzere üniversiteler stratejik planlarındaki misyon ifadesini belirlerken eğitim öğretim ana temasının altında yer alan turizm mesleki eğitime ve turizm teorik bilgisinin pratiğe dönüşümü ile ilgili ifadelere vurgu yaparak turizm ile ilgili hem teorik hem de uygulamanın önemini belirtmişlerdir. Bu çerçevede bir eğitim anlayışlarının olduğunu misyon ifadesiyle göstermeye çalışmışlardır.

Tablo 3'te araştırma işlevine yönelik alt temada yer alan misyon ifadeleri incelendiğinde bilimsel ve teknolojik bilginin üretilmesi ve yayılmasına katkıda bulunmak ifadesi \%27,27 ile en sık karşımıza çıkan alt tema durumundadır. Turizm alanında ulusal ve evrensel sorunlara çözüm önerisi getiren ifadesi ise \%18,18 ile en sık ifade edilen ikinci tema olarak görülmektedir.

Turizm fakültelerinde $\% 18,87$ ile bilimsel ve teknolojik bilginin üretilmesi ve yayılmasına katkıda bulunmak ifadesi ve turizm alanında ulusal ve evrensel sorunlara çözüm önerisi getiren ifadesi en sık tekrarlanan temadır. Turizm yüksekokullarında ise en sık tekrarlanan tema \% 66, 70 ile bilimsel ve teknolojik bilginin üretilmesi ve yayılmasına katkıda bulunmak ifadesi karşımıza çıkmaktadır. En az tekrarlanan alt temalara baktığımızda ise, bilimsel teknolojik gelişmelerin toplum yaşamında, devlet yapısı içerisinde, sanayide ve özel sektörde yaygın olarak kullanılmasına öncülük etmek ve bilimsel üretim yoluyla bilginin teknolojiye dönüşümünü sağlamak alt temaları tercih edildiği görülmektedir.

Turizm fakültelerinde ve turizm yüksekokullarında bilimsel ve teknolojik bilginin üretilmesi üzerinde durulmaktadır. Ayrıca turizm fakültelerinde turizm alanında ulusal ve uluslararası sorunlara çözüm önerisi getirmeyi amaçlayan bir misyonu benimsedikleri görülmektedir. 
Tablo 2. Eğitim Öğretim İşlevine Yönelik Alt Temada Yer Alan Misyon İfadeleri

\begin{tabular}{|c|c|c|c|c|c|c|c|c|c|c|}
\hline \multirow{3}{*}{$\begin{array}{l}\text { Eğitim Öğretim İşlevine Yönelik Alt } \\
\text { Temada Yer Alan Misyon İfadeleri }\end{array}$} & \multicolumn{4}{|c|}{ Turizm Fakülteleri } & \multicolumn{4}{|c|}{$\begin{array}{l}\text { Turizm } \\
\text { Yüksekokulu }\end{array}$} & \multicolumn{2}{|c|}{ Toplam } \\
\hline & \multicolumn{2}{|c|}{ Devlet } & \multicolumn{2}{|c|}{ Vakıf } & \multicolumn{2}{|c|}{ Devlet } & \multicolumn{2}{|c|}{ Vakıf } & \multirow[b]{2}{*}{$\mathrm{f}$} & \multirow[b]{2}{*}{$\%$} \\
\hline & $\mathbf{f}$ & $\%$ & f & $\%$ & f & $\%$ & f & $\%$ & & \\
\hline Turizm mesleki eğitim sunan & 10 & 23,81 & 1 & 100 & 3 & 42,9 & - & - & 14 & 28,00 \\
\hline $\begin{array}{l}\text { Turizm teorik bilgisini pratiğe } \\
\text { dönüştürme imkanı sunan }\end{array}$ & 5 & 11,90 & - & - & 1 & 14,3 & - & - & 6 & 12,00 \\
\hline Çağdaş eğitim sürecine uyumlu & 4 & 9,52 & - & - & - & - & - & - & 4 & 8,00 \\
\hline $\begin{array}{l}\text { Ulusal ve uluslararası platforma tanınan } \\
\text { saygın bir eğitim kurumu }\end{array}$ & 4 & 9,52 & - & - & 1 & 14,3 & - & - & 5 & 10,00 \\
\hline $\begin{array}{l}\text { Ülkemizin ve milletimizin temel } \\
\text { değerleri ve stratejik hedeflerine uygun } \\
\text { bir eğitim anlayışı }\end{array}$ & 4 & 9,52 & - & - & - & - & - & - & 4 & 8,0 \\
\hline Herkes için eğitim olanağı sunan & 3 & 7,14 & - & - & - & - & - & - & 3 & 6,00 \\
\hline $\begin{array}{l}\text { Turizm Otomasyon ve bilgi iletişim } \\
\text { teknolojilerini kullanmak }\end{array}$ & 3 & 7,14 & - & - & 1 & 14,3 & - & - & 4 & 8,00 \\
\hline $\begin{array}{l}\text { Paydaşların gereksinimlerini gözeten } \\
\text { eğitim anlayışı }\end{array}$ & 2 & 4,76 & - & - & - & - & - & - & 2 & 4,00 \\
\hline $\begin{array}{l}\text { Ulusal ve uluslararası yükseköğretim } \\
\text { kurumlarıyla etkileşimleri artırmak }\end{array}$ & 2 & 4,76 & - & - & - & - & - & - & 2 & 4,00 \\
\hline $\begin{array}{l}\text { Bilgi toplumunun oluşmasına katkı } \\
\text { sağlamak }\end{array}$ & 1 & 2,38 & - & - & - & - & - & - & 1 & 2,00 \\
\hline $\begin{array}{l}\text { Türkiye Cumhuriyeti'nin temel } \\
\text { ilkelerine ve bilimin evrensel değerlerine } \\
\text { uygun bir eğitim anlayışı }\end{array}$ & 1 & 2,38 & - & - & - & - & - & - & 1 & 2,00 \\
\hline Eğitim danışmanlığı yapmak & 1 & 2,38 & - & - & - & - & - & - & 1 & 2,00 \\
\hline $\begin{array}{l}\text { Yüksek nitelikli eğitime önem ve öncelik } \\
\text { veren }\end{array}$ & 1 & 2,38 & - & - & 1 & 14,3 & - & - & 2 & 4,00 \\
\hline Öğrenci odaklılık & 1 & 2,38 & - & - & - & - & - & - & 1 & 2,00 \\
\hline Toplam & 42 & 100 & 1 & 100 & 7 & 100 & - & - & 50 & 100 \\
\hline
\end{tabular}


Tablo 3. Araştırma İşlevine Yönelik Alt Temada Yer Alan Misyon İfadeleri

\begin{tabular}{|c|c|c|c|c|c|c|c|c|c|c|}
\hline \multirow{3}{*}{$\begin{array}{l}\text { Araştırma İşlevine Yönelik Alt } \\
\text { Temada Yer Alan Misyon İ́fadeleri }\end{array}$} & \multicolumn{4}{|c|}{ Turizm Fakülteleri } & \multicolumn{4}{|c|}{$\begin{array}{l}\text { Turizm } \\
\text { Yüksekokulu }\end{array}$} & \multicolumn{2}{|c|}{ Toplam } \\
\hline & \multicolumn{2}{|c|}{ Devlet } & \multicolumn{2}{|c|}{ Vakıf } & \multicolumn{2}{|c|}{ Devlet } & \multicolumn{2}{|c|}{ Vakıf } & \multirow[b]{2}{*}{ f } & \multirow[b]{2}{*}{$\%$} \\
\hline & $\mathrm{f}$ & $\%$ & f & $\%$ & f & $\%$ & f & $\%$ & & \\
\hline $\begin{array}{l}\text { Turizm alanında ulusal ve evrensel } \\
\text { sorunlara çözüm önerisi getiren }\end{array}$ & 10 & 18,87 & - & - & 1 & 11,7 & 1 & 50 & 12 & 18,18 \\
\hline $\begin{array}{llcl}\text { Bilimsel } & \text { ve } & \text { teknolojik } & \text { bilginin } \\
\text { üretilmesi } & \text { ve } & \text { yayılmasına } & \text { katkıda } \\
\text { bulunmak } & & & \end{array}$ & 10 & 18,87 & 1 & 50 & 6 & 66,7 & 1 & 50 & 18 & 27,27 \\
\hline $\begin{array}{l}\text { Evrensel düzeyde turizm alanında bilgi } \\
\text { üretmek ve araştırma yapmak }\end{array}$ & 6 & 11,32 & - & - & - & - & - & - & 6 & 9,09 \\
\hline Araştırmacılar yetiştirmek & 5 & 9,43 & - & - & - & - & - & - & 5 & 7,58 \\
\hline $\begin{array}{l}\text { Üretilen bilgiyi ulusal ve uluslararası } \\
\text { alanlarda akademik çevreler ve } \\
\text { toplumla paylaşmak }\end{array}$ & 4 & 7,55 & - & - & - & - & - & - & 4 & 6,06 \\
\hline Proje üretmek ve teşvik etmek & 4 & 7,55 & - & - & 1 & 11,1 & - & - & 5 & 7,58 \\
\hline $\begin{array}{l}\text { Bilim, sanat, kültür ve bilgi birikimine } \\
\text { katkıda bulunmak }\end{array}$ & 3 & 5,66 & - & - & - & - & - & - & 3 & 4,54 \\
\hline $\begin{array}{l}\text { Ülke ve toplumsal gelişimine ve } \\
\text { evrensel bilime katkıda bulunmak }\end{array}$ & 3 & 5,66 & 1 & 50 & 1 & 11,1 & - & - & 5 & 7,58 \\
\hline $\begin{array}{l}\text { Turizm endüstrinin gelişmesine } \\
\text { katkıda bulunmak }\end{array}$ & 2 & 3,77 & - & - & - & - & - & - & 2 & 3,03 \\
\hline $\begin{array}{l}\text { Araştırma ve geliştirmeye destek } \\
\text { vermek }\end{array}$ & 2 & 3,77 & - & - & - & - & - & - & 2 & 3,03 \\
\hline İnsanlığa hizmet etmek & 2 & 3,77 & - & - & - & - & - & - & 2 & 3,03 \\
\hline $\begin{array}{l}\text { Bilimsel teknolojik gelişmelerin toplum } \\
\text { yaşamında, devlet yapısı içerisinde, } \\
\text { sanayide ve özel sektörde yaygın } \\
\text { olarak kullanılmasına öncülük etmek }\end{array}$ & 1 & 1,89 & - & - & - & - & - & - & 1 & 1,51 \\
\hline $\begin{array}{l}\text { Bilimsel üretim yoluyla bilginin } \\
\text { teknolojiye dönüşümünü sağlamak }\end{array}$ & 1 & 1,89 & - & - & - & - & - & - & 1 & 1,51 \\
\hline Toplam & 53 & 100 & 2 & 100 & 9 & 100 & 2 & 100 & 66 & 100 \\
\hline
\end{tabular}


Tablo 4. Toplumsal İşlevine Yönelik Alt Temada Yer Alan Misyon İfadeleri

\begin{tabular}{|c|c|c|c|c|c|c|c|c|}
\hline \multirow{3}{*}{$\begin{array}{l}\text { Toplumsal İşlevine Yönelik Alt } \\
\text { Temada Yer Alan Misyon İfadeleri }\end{array}$} & \multicolumn{3}{|c|}{ Turizm Fakülteleri } & \multicolumn{3}{|c|}{$\begin{array}{l}\text { Turizm } \\
\text { Yüksekokulu }\end{array}$} & \multicolumn{2}{|c|}{ Toplam } \\
\hline & \multicolumn{2}{|c|}{ Devlet } & \multirow{2}{*}{$\begin{array}{l}\text { Vakı } \\
\text { f } \\
\text { f } \%\end{array}$} & \multicolumn{2}{|c|}{ Devlet } & \multicolumn{3}{|l|}{$\begin{array}{l}\text { Va } \\
\text { kıf }\end{array}$} \\
\hline & $\mathbf{f}$ & $\%$ & & f & $\%$ & f $\%$ & f & $\%$ \\
\hline $\begin{array}{l}\text { Ulusal uluslararası toplumsal, kamusal } \\
\text { ve ekonomik aktörlerle ilişkiler kurmak }\end{array}$ & 8 & 28,57 & -- & - & - & -- & 8 & 25,80 \\
\hline $\begin{array}{l}\text { Bölgenin ve ülkenin sürdürebilir } \\
\text { kalkınmasına katkı sağlamak }\end{array}$ & 7 & 26,92 & -- & 1 & $\begin{array}{l}20, \\
00\end{array}$ & - & 8 & 25,80 \\
\hline $\begin{array}{l}\text { Bölgenin ekonomik gelişimine katkı } \\
\text { sağlamak }\end{array}$ & 3 & 11,54 & -- & - & - & -- & 3 & 9,68 \\
\hline Toplumun gelişimine öncülük etmek & 2 & 7,69 & - & - & - & - & 2 & 6,45 \\
\hline Yenilikçi toplumsal projeler üretmek & 1 & 3,85 & -- & - & - & -- & 1 & 3,22 \\
\hline Ürettiklerini toplum yararına sunmak & 1 & 3,85 & - & - & - & - & 1 & 3,22 \\
\hline $\begin{array}{l}\text { Evrensel ve yerel sorunların çözümüne } \\
\text { katkıda bulunmak }\end{array}$ & 1 & 3,85 & -- & 1 & $\begin{array}{l}20, \\
00\end{array}$ & - & 2 & 6,45 \\
\hline $\begin{array}{l}\text { Ülkenin gelişme düzeyi ve yaşam } \\
\text { kalitesinin artmasına katkı sağlamak }\end{array}$ & 1 & 3,85 & - & - & - & - & 1 & 3,22 \\
\hline Dünyaya uyum sağlayan & 1 & 3,85 & -- & - & - & - & 1 & 3,22 \\
\hline $\begin{array}{l}\text { Toplumu turizm konusunda } \\
\text { bilgilendirmek }\end{array}$ & 1 & 3,85 & -- & - & - & - & 1 & 3,22 \\
\hline $\begin{array}{l}\text { Toplumun sosyal, kültürel, sanatsal ve } \\
\text { sportif gelişimine katkı sağlayacak } \\
\text { etkinlikler düzenlemek }\end{array}$ & 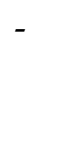 & - & -- & 3 & $\begin{array}{l}60, \\
00\end{array}$ & -- & 3 & 6,45 \\
\hline Toplam & 26 & 100 & - & 5 & 100 & - & 31 & 100 \\
\hline
\end{tabular}

Tablo 4'te toplumsal işlevine yönelik alt temada yer alan misyon ifadeleri incelendiğinde $\% 25,80$ ile ulusal ve uluslararası toplumsal, kamusal ve ekonomik aktörlerle ilişkiler kurmak ile bölgenin ve ülkenin sürdürebilir kalkınmasına katkı sağlamak alt temaları yer aldığı görülmektedir. Turizm fakülteleri ve turizm yüksekokulları boyutu ile bakıldığında da durumun değişmediği ve aynı alt temaların yer aldığı görülmektedir. En az sıklıkta yer alan alt temalar ise, yenilikçi toplumsal projeler üretmek, ürettiklerini toplum yararına sunmak, ülkenin gelişme düzeyi ve 
yaşam kalitesinin artmasına katkı sağlamak, dünyaya uyum sağlayan ve toplumu turizm konusunda bilgilendirmek alt temaları olduğu ifade edilebilmektedir.

Tablo 5. İnsan Kaynakları İşlevine Yönelik Alt Temada Yer Alan Misyon İfadeleri

\begin{tabular}{|c|c|c|c|c|c|c|c|c|c|c|}
\hline \multirow{3}{*}{$\begin{array}{l}\text { İnsan Kaynakları İşlevine Yönelik } \\
\text { Alt Temada Yer Alan Misyon } \\
\text { İfadeleri }\end{array}$} & \multicolumn{4}{|c|}{ Turizm Fakülteleri } & \multicolumn{4}{|c|}{ Turizm Yüksekokulu } & \multicolumn{2}{|c|}{ Toplam } \\
\hline & \multicolumn{2}{|c|}{ Devlet } & \multicolumn{2}{|c|}{ Vakıf } & \multicolumn{2}{|c|}{ Devlet } & \multicolumn{2}{|c|}{ Vakıf } & \multirow[b]{2}{*}{$\mathbf{f}$} & \multirow[b]{2}{*}{$\%$} \\
\hline & $\mathbf{f}$ & $\%$ & $\mathbf{f}$ & $\%$ & f & $\%$ & f & $\%$ & & \\
\hline $\begin{array}{l}\text { Turizmde yeterli ve yetkin bilgiye } \\
\text { sahip olmak }\end{array}$ & 24 & 34,78 & 1 & 50 & 5 & 33,3 & - & - & 30 & 34,48 \\
\hline Girişimci üretken olmak & 6 & 8,70 & - & - & 2 & 13,3 & - & - & 8 & 9,20 \\
\hline $\begin{array}{l}\text { Toplumsal sorumluluk } \\
\text { gelişmiş }\end{array}$ & 5 & 7,25 & - & - & 1 & 6,7 & 1 & 50 & 7 & 8,04 \\
\hline Toplumsal değerlere bağlı & 4 & 5,80 & - & - & 1 & 6,7 & - & - & 5 & 5,75 \\
\hline Etik değerlere bağlı & 4 & 5,80 & - & - & 1 & 6,7 & 1 & 50 & 6 & 6,90 \\
\hline Atatürk ilkelerine bağlı & 3 & 4,35 & - & - & - & - & - & - & 3 & 3,44 \\
\hline Rekabetçi & 3 & 4,35 & - & - & 1 & 6,7 & - & - & 4 & 4,60 \\
\hline Yaraticı & 3 & 4,35 & - & - & 1 & 6,7 & - & - & 4 & 4,60 \\
\hline $\begin{array}{l}\text { Çevresel, kültürel, tarihsel değerleri } \\
\text { yücelten }\end{array}$ & 3 & 4,35 & - & - & - & - & - & - & 3 & 3,44 \\
\hline Özgür düşünen & - & - & 1 & 50 & - & - & - & - & 1 & 1,14 \\
\hline Eleştiren & 2 & 2,90 & - & - & 1 & 6,7 & - & - & 3 & 3,44 \\
\hline Takım çalışmasına yatkın & 2 & 2,90 & - & - & 1 & 6,7 & - & - & 3 & 3,44 \\
\hline Katılımcı & 2 & 2,90 & - & - & 1 & 6,7 & - & - & 3 & 3,44 \\
\hline Pozitivist düşünen & 2 & 2,90 & - & - & - & - & - & - & 2 & 2,30 \\
\hline $\begin{array}{l}\text { Ulusal ve uluslararası düzeyde } \\
\text { yarışan }\end{array}$ & 2 & 2,90 & - & - & - & - & - & - & 2 & 2,30 \\
\hline Pozitif düşünen (olumlu) & 1 & 1,45 & - & - & - & - & - & - & 1 & 1,14 \\
\hline Ülkesini tüm dünyada temsil eden & 1 & 1,45 & - & - & - & - & - & - & 1 & 1,14 \\
\hline Bilgi ve teknoloji üreten & 1 & 1,45 & - & - & - & - & - & - & 1 & 1,14 \\
\hline Toplam & 68 & 100 & 2 & 100 & 15 & 100 & 2 & 100 & 87 & 100 \\
\hline
\end{tabular}


Turizm fakülteleri ve turizm yüksekokullarında ulusal ve uluslararası boyutta her türlü işbirliği kurulmasının önemi ilgili misyon ifadelerinde belirtildiği görülmektedir. Bu durum ise, işbirliğinin her sektörde ve her kesimde önemli olduğunu göstermektedir. Ayrıca üniversitenin temel amaçları arasında yer alan toplumsal kalkınmanın ve bu kalkınmanın devamlılığına vurgu yapıldığı ve ortak bir amaç olduğu görülmektedir.

Tablo 5'te insan kaynakları işlevine yönelik alt temada yer alan misyon ifadeleri incelendiğinde $\% 34,48$ ile turizmde yeterli ve yetkin bilgiye sahip olmak alt temasına rastlanma sıklığı en fazla olan tema olarak görülmektedir. Bu durumun turizm fakültesi ve turizm yüksekokullarda da değişmediği görülmüştür. En az sıklığa sahip alt temalar ise; özgür düşünen, pozitif (olumlu) düşünen, ülkesini tüm dünyada temsil eden ve bilgi ve teknoloji üreten şeklinde karşımıza çıkmaktadır. Bu bağlamda, sektördeki iş gücünü sağlamasının yanında turizm ile ilgili bilgi ve beceriye sahip olunması gerekliliğini vurgulamakta ve böylece sektörün istemiş olduğu iş gücünün sağlanacağı belirtilerek farklılık yaratmaya çalışıldığı görülmektedir.

Tablo 6. Turizm Fakülteleri ve Turizm Yüksekokullarının Stratejik Planlarında Yer Alan Vizyon İfadelerinin Ana Temalara Göre Dağılımı

\begin{tabular}{|c|c|c|c|c|c|c|c|c|c|c|}
\hline \multirow[t]{3}{*}{$\begin{array}{l}\text { Vizyon İfadelerinde Yer } \\
\text { Alan Ana Temalar }\end{array}$} & \multicolumn{4}{|c|}{ Turizm Fakülteleri } & \multicolumn{4}{|c|}{$\begin{array}{l}\text { Turizm } \\
\text { Yüksekokulu }\end{array}$} & \multicolumn{2}{|c|}{ Toplam } \\
\hline & \multicolumn{2}{|c|}{ Devlet } & \multicolumn{2}{|c|}{ Vakıf } & \multicolumn{2}{|c|}{ Devlet } & \multicolumn{2}{|c|}{ Vakıf } & \multirow[b]{2}{*}{ f } & \multirow[b]{2}{*}{$\%$} \\
\hline & f & $\%$ & f & $\%$ & $\mathbf{f}$ & $\%$ & $\mathbf{f}$ & $\%$ & & \\
\hline $\begin{array}{l}\text { Eğitim Öğretim İşlevi Ana } \\
\text { Teması }\end{array}$ & 33 & 32,67 & 1 & 33,3 & 7 & $\begin{array}{l}24,1 \\
3\end{array}$ & 2 & $\begin{array}{l}66 \\
7\end{array}$ & 43 & 31,61 \\
\hline Araştırma İşlevi Ana Teması & 25 & 24,75 & 1 & 33,3 & 11 & $\begin{array}{l}37,9 \\
3\end{array}$ & 1 & $\begin{array}{l}33 \\
3\end{array}$ & 38 & 27,94 \\
\hline Toplumsal İşlev Ana Teması & 17 & 16,83 & - & - & 3 & $\begin{array}{l}10,3 \\
4\end{array}$ & - & - & 20 & 14,71 \\
\hline $\begin{array}{l}\text { İnsan Kaynakları İşlevi Ana } \\
\text { Teması }\end{array}$ & 26 & 25,74 & 1 & 33,3 & 8 & $\begin{array}{l}27,5 \\
9\end{array}$ & - & - & 35 & 25,73 \\
\hline Toplam & 101 & 100 & 3 & 100 & 29 & 100 & 3 & 100 & 136 & 100 \\
\hline
\end{tabular}

Tablo 6'da ise turizm fakülteleri ve turizm yüksekokullarının stratejik planlarında yer alan vizyon ifadelerinin ana temalara göre dağılımı verilmiştir. Bu kapsamda 52 fakülte ve yüksekokulların vizyon ifadelerinden toplam 232 farklı mesaj tespit edilmiştir. Ana temalar arasında en çok vurgulanan tema \%31,61 ile eğitim öğretim işlevi ana teması ilk sırada yer alırken, toplumsal işlev ana teması \%14,71 ile en az sıklığa sahip tema olarak karşımıza çıkmaktadır. Turizm fakültelerinde en sık rastlanan tema eğitim öğretim işlevi ana teması olurken turizm yüksekokullarında en sık rastlanan ana tema araştırma işlevi olarak görülmektedir. Bu durum turizm fakültelerinin vizyon ifadelerinde genellikle eğitim öğretim unsurlarına öncelik verildiği 
ve bu tema üzerine vurgu yapıldığı görülürken, turizm yüksekokullarında araştırma unsurlarına öncelik verilmekte ve bu tema üzerine vurgu yapıldığı görülmektedir.

Tablo 7. Eğitim Öğretim İşlevine Yönelik Alt Temada Yer Alan Misyon İfadeleri

\begin{tabular}{|c|c|c|c|c|c|c|c|c|}
\hline \multirow{3}{*}{$\begin{array}{l}\text { Eğitim Öğretim İşlevine Yönelik } \\
\text { Alt Temada Yer Alan Vizyon } \\
\text { İfadeleri }\end{array}$} & \multicolumn{3}{|c|}{ Turizm Fakülteleri } & \multicolumn{3}{|c|}{$\begin{array}{l}\text { Turizm } \\
\text { Yüksekokulu }\end{array}$} & \multicolumn{2}{|c|}{ Toplam } \\
\hline & \multicolumn{2}{|c|}{ Devlet } & Vakıf & \multicolumn{2}{|c|}{ Devlet } & Vakıf & & \\
\hline & $\mathbf{f}$ & $\%$ & f $\%$ & $\mathbf{f}$ & $\%$ & f $\%$ & $\mathbf{f}$ & $\%$ \\
\hline $\begin{array}{l}\text { Ulusal ve uluslararası düzeyde } \\
\text { eğitim ve öğretimde lider, tercih } \\
\text { edilen ve saygınlığı olan }\end{array}$ & 10 & 30,30 & 1100 & 4 & 57,1 & - & 15 & 34,88 \\
\hline $\begin{array}{l}\text { Uluslararası nitelikte öğrenci ve } \\
\text { öğretim elemanı yapısına sahip }\end{array}$ & 7 & 21,21 & -- & 1 & 14,3 & 150 & 9 & 20,93 \\
\hline $\begin{array}{l}\text { Ĕ̆itimde kalite } \quad \text { yönetimini } \\
\text { benimsemiş }\end{array}$ & 7 & 21,21 & -- & - & - & - & 7 & 16,27 \\
\hline $\begin{array}{l}\text { Bölgesinde en önemli eğitim } \\
\text { merkezi olmak }\end{array}$ & 4 & 12,12 & - & - & - & - & 4 & 9,30 \\
\hline $\begin{array}{l}\text { Yüksek katma değerde bilgi ve } \\
\text { hizmet üretmek }\end{array}$ & 3 & 9,09 & - & - & - & - & 3 & 6,98 \\
\hline Çeşitli alanlarda uzmanlaşma & 1 & 3,03 & - & 2 & 28,6 & - & 1 & 2,32 \\
\hline $\begin{array}{lrr}\text { Ülkemizin } & \text { çağdaş } & \text { uygarlık } \\
\text { düzeyinin } & \text { üzerine } & \text { çıkmasına } \\
\text { katkıda bulunacak eğitim } & \text { anlayışı }\end{array}$ & 1 & 3,03 & - & - & - & - & 1 & 2,32 \\
\hline $\begin{array}{l}\text { Toplumsal gelişmeye hizmet eden } \\
\text { eğitim anlayışı }\end{array}$ & - & - & $-\quad-$ & - & - & 150 & 1 & 2,32 \\
\hline Toplam & 33 & 100 & 1100 & 7 & 100 & 2100 & 43 & 100 \\
\hline
\end{tabular}

Tablo 7'de eğitim öğretim işlevine yönelik alt temada yer alan vizyon ifadeleri gösterilmektedir. Üniversitenin bilgi üreten bir kurum olduğu ve bu bilgi ile yenilikler, çeşitli alanlarda gelişmeler yaratacağını ve bu sayede ulusal ve uluslararası alanlarda tanınan ve saygın bir üniversite olmak yolunda önemli bir adım olarak görülmektedir. (Çiçek ve Taş, 2019: 555-556). Tablo incelendiğinde de $\% 34,88$ ile ulusal ve uluslararası düzeyde eğitim ve öğretimde lider, tercih edilen ve saygınlığı olan alt teması en fazla rastlanma sıklığı olarak görülmektedir. Bu durum turizm fakülteleri ve turizm yüksekokullarında en çok karşılaşılan tema olduğu ifade edilebilir. Tabloda en az sıklık yüzdesine sahip olan ifadeler ise; çeşitli alanlarda uzmanlaşma, ülkemizin çağdaş uygarlık düzeyinin üzerine çıkmasına katkıda bulunacak eğitim anlayışı ve toplumsal 
gelişmeye hizmet eden eğitim anlayışı olarak karşımıza çıkmaktadır. Turizm fakülteleri ve turizm yüksekokullarının vizyon ifadelerinde görüldüğü gibi her zaman geliştirmeyi sürekli hale getirerek gelecekte de saygın ve tercih edilen bir fakülte ya da yüksekokul olmayı hedefledikleri söylenebilir.

Tablo 8. Araştırma İşlevine Yönelik Alt Temada Yer Alan Vizyon İfadeleri

\begin{tabular}{|c|c|c|c|c|c|c|c|c|c|c|}
\hline \multirow{3}{*}{$\begin{array}{l}\text { Araştırma İşlevine Yönelik Alt } \\
\text { Temada Yer Alan Vizyon } \\
\text { İfadeleri }\end{array}$} & \multicolumn{4}{|c|}{ Turizm Fakülteleri } & \multicolumn{4}{|c|}{$\begin{array}{l}\text { Turizm } \\
\text { Yüksekokulu }\end{array}$} & \multicolumn{2}{|c|}{ Toplam } \\
\hline & \multicolumn{2}{|c|}{ Devlet } & \multicolumn{2}{|c|}{ Vakıf } & \multicolumn{2}{|c|}{ Devlet } & \multicolumn{2}{|c|}{ Vakıf } & \multirow[b]{2}{*}{$\mathbf{f}$} & \multirow[b]{2}{*}{$\%$} \\
\hline & $\mathbf{f}$ & $\%$ & $\mathbf{f}$ & $\%$ & $\mathbf{f}$ & $\%$ & $\mathbf{f}$ & $\%$ & & \\
\hline $\begin{array}{l}\text { Yurt içi ve yurt dışında tanınan } \\
\text { saygın, lider bir araştırma } \\
\text { üniversite olmak }\end{array}$ & 10 & 40,00 & 1 & 100 & 2 & 18,2 & 1 & 100 & 14 & 36,84 \\
\hline $\begin{array}{l}\text { Dünya üniversiteleri arasına } \\
\text { girmeye çalışmak }\end{array}$ & 5 & 20,00 & - & - & - & - & - & - & 5 & 13,16 \\
\hline $\begin{array}{l}\text { Sektöre yön veren projeler } \\
\text { yetiştirmektir }\end{array}$ & 3 & 12,00 & - & - & - & - & - & - & 3 & 7,89 \\
\hline $\begin{array}{l}\text { Yenilikleri takip ederek kaliteyi } \\
\text { sürekli iyileştirmek }\end{array}$ & 2 & 8,00 & - & - & 5 & 45,5 & - & - & 7 & 18,42 \\
\hline $\begin{array}{l}\text { Ulusal ve bölgesel sorunlara } \\
\text { odaklı araştırmalar üretmek }\end{array}$ & 2 & 8,00 & - & - & 1 & 9,1 & - & - & 3 & 7,89 \\
\hline $\begin{array}{l}\text { Ulusal ve uluslararası rekabet } \\
\text { gücüne sahip olmak }\end{array}$ & 2 & 8,00 & - & - & - & - & - & - & 2 & 5,26 \\
\hline $\begin{array}{l}\text { Turizm için yararlı bilimsel bilgi } \\
\text { üretmek ve kullanmak }\end{array}$ & 1 & 4,00 & - & - & 1 & 9,1 & - & - & 2 & 5,26 \\
\hline $\begin{array}{l}\text { Dünya standartlarında teknoloji } \\
\text { üretmek }\end{array}$ & - & - & - & - & 1 & 9,1 & - & - & 1 & 2,63 \\
\hline $\begin{array}{l}\text { Bilimsel değerleri yaşamla } \\
\text { özdeşleştirmek }\end{array}$ & - & - & - & - & 1 & 9,1 & - & - & 1 & 2,63 \\
\hline Toplam & 25 & 100 & 1 & 100 & 11 & 100 & 1 & 100 & 38 & 100 \\
\hline
\end{tabular}

Tablo 8' de araştırma işlevine yönelik alt temada yer alan vizyon ifadeleri gösterilmektedir. Tablo incelendiğinde en fazla sıklığa sahip olan alt tema \%36,84 ile yurt içi ve yurt dişında tanınan saygın, lider bir araştırma üniversite olmak ifadesi yer almaktadır. Turizm fakültesinde de aynı alt tema en sık rastlanan alt tema olurken turizm yüksekokullarında en sık rastlanan alt tema $\% 45,5$ ile yenilikleri takip ederek kaliteyi sürekli iyileştirmek ifadesi tespit edilmiştir. Araştırma 
işlevine yönelik alt temalar tablosunda en az sıklık yüzdesine sahip alt temalar; dünya standartlarında teknoloji üretmek ve bilimsel değerleri yaşamla özdeşleştirmek olarak görülmektedir.

Üniversitelerin öncelikli amaçları arasında eğitim öğretim ve araştırma gelmektedir. Bu çerçevede turizm fakülteleri ve turizm yüksekokulları da gelecekte araştırmacı lider bir kuruma dönüşmeyi amaçlamaktadırlar.

Tablo 9' da toplumsal işlevine yönelik alt temada yer alan vizyon ifadeleri gösterilmektedir. Genel olarak üniversitelerin büyük bir bölümü ulusal ve uluslararası seviyede tanınan, lider bir üniversite olmayı hedeflemektedir (Özdem, 2011:1885). Tablo incelendiğinde en fazla sıklığa sahip olan alt tema $\% 25,00$ ile toplumun aydınlanmasına ve gelişmesine hizmet etmek ifadesi yer almaktadır. Turizm fakültesinde ise $\% 25,00$ ile hem toplumun aydınlanmasına ve gelişmesine hizmet etmek ifadesi hem de ekonomi, teknoloji ve sosyal gelişimleri dikkate almak alt temaları en sık rastlanan ifadeler olarak görülmektedir. Turizm yüksekokulunda ise en sık rastlanan alt temalar toplumun aydınlanmasına ve gelişmesine hizmet etmek, üniversite, sanayi, toplum işbirliğini gerçekleştirmek ve yaşam niteliğinin yükseltilmesine katkıda bulunmak olarak karşımıza çıkmasına rağmen turizm yüksekokulu sayısının azlığı nedeniyle herhangi bir yorum tam olarak gerçeği yansıtamayacaktır.

Tablo 9. Toplumsal İşlevine Yönelik Alt Temada Yer Alan Vizyon İfadeleri

\begin{tabular}{|c|c|c|c|c|c|c|c|c|c|}
\hline \multirow{3}{*}{$\begin{array}{l}\text { Toplumsal İşlevine Yönelik Alt Temada } \\
\text { Yer Alan Vizyon İfadeleri }\end{array}$} & \multicolumn{3}{|c|}{$\begin{array}{l}\text { Turizm } \\
\text { Fakülteleri }\end{array}$} & \multicolumn{4}{|c|}{$\begin{array}{l}\text { Turizm } \\
\text { Yüksekokulu }\end{array}$} & \multicolumn{2}{|c|}{ Toplam } \\
\hline & \multicolumn{2}{|c|}{ Devlet } & $\begin{array}{l}\text { Va } \\
\text { kıf }\end{array}$ & \multicolumn{2}{|c|}{ Devlet } & \multicolumn{2}{|c|}{$\begin{array}{l}\text { Vak } \\
\text { If }\end{array}$} & & \\
\hline & $\mathbf{f}$ & $\%$ & f $\%$ & $\mathrm{f}$ & $\%$ & f & $\%$ & $\mathbf{f}$ & $\%$ \\
\hline $\begin{array}{l}\text { Ekonomi, teknoloji ve sosyal gelişimleri } \\
\text { dikkate almak }\end{array}$ & 4 & 23,53 & -- & - & - & - & - & 4 & 20,00 \\
\hline $\begin{array}{l}\text { Toplumun aydınlanmasına ve gelişmesine } \\
\text { hizmet etmek }\end{array}$ & 4 & 23,53 & -- & 1 & 33,3 & - & - & 5 & 25,00 \\
\hline Dil, kültür, sanat değerlerini korumak & 3 & 17,65 & -- & - & - & - & - & 3 & 12,00 \\
\hline $\begin{array}{l}\text { Üniversite, sanayi, toplum işbirliğini } \\
\text { gerçekleştirmek }\end{array}$ & 2 & 11,76 & -- & 1 & 33,3 & - & - & 3 & 12,00 \\
\hline Doğa ve çevre dostu & 2 & 11,76 & -- & - & - & - & - & 2 & 10,00 \\
\hline Sosyal bir öğrenim merkezi olmak & 1 & 5,88 & -- & - & - & - & - & 1 & 5,00 \\
\hline $\begin{array}{l}\text { Yaşam niteliğinin yükseltilmesine katkıda } \\
\text { bulunmak }\end{array}$ & 1 & 5,88 & -- & 1 & 33,3 & - & - & 2 & 10,00 \\
\hline Toplam & 17 & 100 & - & 3 & 100 & - & - & 20 & 100 \\
\hline
\end{tabular}


Tablo 10'da insan kaynakları işlevine yönelik alt temada yer alan vizyon ifadeleri gösterilmektedir. Tablo incelendiğinde \% 31,43 ile mezunları tercih edilen ve aranan bireyler yetiştirmek alt teması en fazla rastlanma sıklığı olarak görülmektedir. Bu durum turizm fakülteleri ve turizm yüksekokullarında en çok karşılaşılan tema olduğu ifade edilebilir. Tabloda en az sıklık yüzdesine sahip olan ifadeler ise; nitelikli insan gücü kaynağına yönelik hizmetler ve ülkenin ihtiyaç duyduğu alanlarda meslek elemanı yetiştirmek olarak karşımıza çıkmaktadır. Fakülte ve yüksekokullun tercih edilebilirliğini arttırmak için diğer üniversitelere göre mezun öğrencilerde, diğer üniversiteden mezun olan öğrencilere göre fark yaratacağı ifadelerini ön plana çıkararak geleceğe yönelik bir vizyon ortaya koymaktadırlar.

Tablo 10. İnsan Kaynakları İşlevine Yönelik Alt Temada Yer Alan Vizyon İfadeleri

\begin{tabular}{|c|c|c|c|c|c|c|c|c|}
\hline \multirow{3}{*}{$\begin{array}{l}\text { İnsan Kaynakları İşlevine Yönelik Alt } \\
\text { Temada Yer Alan Vizyon İfadeleri }\end{array}$} & \multicolumn{3}{|c|}{ Turizm Fakülteleri } & \multicolumn{3}{|c|}{$\begin{array}{l}\text { Turizm } \\
\text { Yüksekokulu }\end{array}$} & \multicolumn{2}{|c|}{ Toplam } \\
\hline & \multicolumn{2}{|c|}{ Devlet } & \multirow{2}{*}{$\begin{array}{l}\text { Vakıf } \\
\text { f } \%\end{array}$} & \multicolumn{2}{|c|}{ Devlet } & \multicolumn{3}{|l|}{ Vakı } \\
\hline & $\mathbf{f}$ & $\%$ & & $\mathrm{f}$ & $\%$ & f $\%$ & $\mathbf{f}$ & $\%$ \\
\hline $\begin{array}{l}\text { Mezunları tercih edilen ve aranan } \\
\text { bireyler yetiştirmek }\end{array}$ & 7 & 26,92 & - & 4 & 50,00 & - & 11 & 31,43 \\
\hline $\begin{array}{l}\text { Evrensel değerlere sahip, üstün nitelikli } \\
\text { bireyler yetiştirmek }\end{array}$ & 6 & 23,08 & - & - & - & - & 6 & 17,14 \\
\hline $\begin{array}{l}\text { Kendini yenileyen ve geliştiren, } \\
\text { kendisiyle ve çevresiyle iletişimi } \\
\text { kuvvetli, üretken bireyler yetiştirmek }\end{array}$ & 5 & 19,23 & - & - & - & - & 5 & 14,29 \\
\hline Gelecek liderleri yetiştirmek & 3 & 11,54 & 1100 & 2 & 25,00 & - & 6 & 17,14 \\
\hline $\begin{array}{l}\text { Küresel rekabet koşullarına hazır nesiller } \\
\text { yetiştirmek }\end{array}$ & 2 & 7,69 & -- & 1 & 12,5 & - & 3 & 8,57 \\
\hline Akademik elemanlar yetiştirmek & 2 & 7,69 & - & - & - & - & 2 & 5,71 \\
\hline $\begin{array}{l}\text { Nitelikli insan gücü kaynağına yönelik } \\
\text { hizmetler }\end{array}$ & 1 & 3,8 & - & - & - & - & 1 & 2,85 \\
\hline $\begin{array}{l}\text { Ülkenin ihtiyaç duyduğu alanlarda } \\
\text { meslek elemanı yetiştirmek }\end{array}$ & - & - & - & 1 & 12,5 & - & 1 & 2,85 \\
\hline Toplam & 26 & 100 & 1100 & 8 & 100 & - - & 35 & 100 \\
\hline
\end{tabular}




\section{SONUÇ ve ÖNERI}

$\mathrm{Bu}$ araştırma turizm fakülteleri ve turizm yüksekokullarının stratejik planlarında yer alan misyon ve vizyon ifadelerini içerik analizi ile incelenmesini amacıyla yapılmıştır. Araştırma sonucuna göre turizm fakülteleri ve turizm yüksekokullarının misyon ifadelerinde insan kaynakları işlevi ana teması ön plana çıkmaktadır. Araştırmada turizm fakülteleri ve turizm yüksekokulları misyon ifadelerini belirlerken turizm mesleki eğitime ve turizm teorik bilgisinin pratiğe dönüşümü vurgusunun sıklıkla yapıldığı görülmektedir. Bu sonuca göre, turizm fakültelerinin ve turizm yüksekokullarının turizm eğitiminin yanında öğrenmiş oldukları mesleki bilgiyi uygulamaya geçirmenin önemine vurgu yapıldığı görülmektedir. Turizm fakültelerinde ve turizm yüksekokullarında bilimsel ve teknolojik bilginin üretilmesi ve yayılmasına katkıda bulunmak alt teması ön plana çıkarken, turizm yüksekokullarından farklı olarak turizm fakültelerinde turizm alanında ulusal ve uluslararası sorunlara çözüm önerisi getiren bir misyonu olduğu ifade edilebilir. Turizm fakülteleri ve turizm yüksekokullarında bildirilen misyon ifadelerinin ulusal ve uluslararası toplumsal, kamusal ve ekonomik aktörlerle ilişkiler kurmak ile bölgenin ve ülkenin sürdürebilir kalkınmasına katkı sağlamak alt temalarının ön plana çıktığı görülmektedir. Lisans eğitimi veren turizm eğitim kurumlarında işbirliğine önem verdiği görülmekte ve ayrıca özelde bölge gelişimi olmakla birlikte genelde ülke kalkınmasını görev edindiği söylenebilmektedir.

Araştırma sonucuna göre turizm fakültelerinin vizyon ifadelerinde eğitim öğretim işlevi ana teması ön plana çıkmaktadır. Turizm yüksekokullarında ise, araştırma işlevi ana teması üzerinde durulmaktadır. Turizm fakültelerinde yurt içi ve yurt dışında tanınan saygın, lider bir araştırma üniversite olmak vizyonu ön plana çıkmaktadır. Turizm yüksekokullarında ise, yenilikleri takip ederek kaliteyi sürekli iyileştirmek vizyonuna vurgu yapıldığı söylenebilir. Turizm fakülteleri ve turizm yüksekokullarının insan kaynakları ana teması altında yer alan, mezunları tercih edilen ve aranan bireyler yetiştirmek alt teması ile turizm eğitimini sektörün ihtiyaçlarına uyumlu bir şekilde gerçekleştirmeye çalıştığını vizyon bildirileri içerisinde görmekteyiz. Örgütleri başarıya götüren unsurların başında gelen stratejik planlama ve bu planlamanın en önemli unsurları olan vizyon ve misyon ifadelerinin örgütün amacına uygun bir şekilde en doğru biçimde belirlenmesi gerekmektedir. Misyon ifadesi bir örgütün var olma sebebini ortaya koyarken, vizyon ifadesi ise, örgütlerin kurumsal kimliklerini ortaya çıkarmaktadır. Turizm fakülteleri ve turizm yüksekokullarının stratejik planları kapsamında belirlemiş oldukları misyon ve vizyon ifadelerinin büyük oranda paralellik gösterdiği görülmüştür.

Misyon ve vizyon ifadeleri belirlenirken daha sade anlaşıllır ve hedeflenen amaca ulaşılabilir bir şekilde en kısa cümlelerle ifade edilmesi herkes tarafından rahatlıkla anlaşılmasını sağlayacaktır. Turizm fakültelerinin ve turizm yüksekokullarının bildirmiş oldukları misyon ve vizyon ifadeleri sadece yazılı olarak kalmamalı, bu amaçlar eyleme dönüştürülebilir bir şekilde belirlenmelidir. Araştırmada sadece turizm fakülteleri ve turizm yüksekokulları ele alınarak incelenmiştir. Yüksek öğretim düzeyinde turizm eğitimine bakılabilmesi açısından turizm meslek yüksekokullarının da çalışmaya dahil edilerek genişletilmesi sonraki araştırmacılara önerilmektedir.

\section{KAYNAKÇA}

Acar, E. (2007). Yarı Resmi Bir Örgütte Stratejik Planlama Uygulaması: Aydın Ticaret Odası Örneği, Yayınlanmamış Yüksek Lisans Tezi, Adnan Menderes Üniversitesi, Sosyal Bilimler Enstitüsü, Aydin. 
Başpınar, N.Ö. (2020). Vakıf Üniversitelerinin Web Sayfalarındaki Misyon ve Vizyon İfadelerinde Etik Vurgular Üzerine Bir Araştırma, İşletme Araştırmaları Dergisi, 12(1), 469-488.

Boerema, A. J. (2006). An Analysis of Private School Mission Statements, Peabody Journal of Education, 81(1), 180-202.

Bowen, S. A. (2018). Mission and Vision, (Editor) Heath, R. L.: The International Encyclopedia of Strategic Communication, (pp. 1-9). Hoboken, NJ: Wiley.

Çalık, T. (2003). Eğitimde Stratejik Planlama ve Okulların Stratejik Planlama Açısından Nitel Değerlendirilmesi, Kastamonu Eğitim Dergisi, 11(2), 251-268.

Çetin, S. (2009). Vizyon Yönetimi, Selçuk Üniversitesi Sosyal Bilimler Enstitüsü Dergisi, (22), 95-103.

Dinçer, Ö. (2013). Stratejik Yönetim ve İşletme Politikası, İstanbul: Alfa Yayınları.

Doğan, B. (2007). Stratejik Yönetim Alanında Vizyon Kavramının İçeriği Üzerine Bir Çalışma, Öneri Dergisi, 7 (27), 37-47.

Firmin, M. W. and Gilson, K. M. (2009). Mission Statement Analysis of CCCU Member Institutions, Christian Higher Education, 9(1), 60-70.

Ginter, P., Duncan, W. J. and Swayne, L. E. (2013). The Strategic Management of Health Care Organizations (7. Edition). San Francisco: Jossey-Bass, 5-198.

Gültekin, M. C. ve Mazı, F. (2016). Stratejik Planlama ve Stratejik Yönetim Uygulamalarının Meslek Yüksekokulları Açısından Önemi, Akademik Bakış Uluslararası Hakemli Sosyal Bilimler Dergisi, (55), 450-464.

Gürer, H. (2006). Stratejik Planlamanın Temelleri ve Türk Kamu Yönetiminde Uygulanmasına Yönelik Öneriler, Sayıştay Dergisi, 63, 91-105

James, H. and Huisman, J. (2009). Missions Statements in Wales: The Impact of Markets and Policy on Congruence Between Institutions, Journal of Higher Education Policy and Management, 31(1), 23-35.

Kılıç, M. (2010). Stratejik Yönetim Sürecinde Değerler, Vizyon ve Misyon Kavramları Arasındaki İlişki, Sosyo Ekonomi Dergisi, Temmuz-Aralık, 82-98.

Morphew, C. and Hartley, M. (2006). Mission Statements: A Thematic Analysis of Rhetoric Across Institutional Type. The Journal of Higher Education, 77 (3), 456-471.

Muslu, Ş. (2014). Örgütlerde Misyon ve Vizyon Kavramlarının Önemi, Uluslararası Emek ve Toplum Dergisi, 3(5), 150-171.

Özdem, G. (2011). Yükseköğretim Kurumlarının Stratejik Planlarında Yer Alan Vizyon ve Misyon İfadelerinin Analizi, Kuram ve Uygulamada Eğitim Bilimleri Dergisi, 11(4),1869-1894.

Sökmen, A. (2016). İşletmelerde Yönetim ve Organizasyon, Ankara: Detay Yayıncılık.

Taş, M A., Çiçek, H., ve Yastığlu, S. Misyon, Vizyon ve Amaçlar Bağlamında Geleceğe Bakış: Mehmet Akif Ersoy Üniversitesi Stratejik Plan Çalışmaları Örneği, Mehmet Akif Ersoy Üniversitesi İktisadi ve İdari Bilimler Fakültesi Dergisi, 6(2), 544-562.

Ülgen, H. ve Mirze S. K. (2014). İşletmelerde Stratejik Yönetim, İstanbul: Beta Basım Yayım Dağıtım. Üzün, C. (2000). Stratejik Yönetim ve Halkla İlişkiler, İzmir: Dokuz Eylül Yayınları. 
YÖKAK, (2019a). Yüksek Öğretim Kalite Kurulu Genel Değerlendirme Raporu. [Online] https://yokak.gov.tr/Common/Docs/Site_degerlendirme_prog_doc/GenelDegerlendirme2015201 9.pdf [Erişim Tarihi: 30.05.2020].

YÖKAK, (2019b). 20182019 Yükseköğretim Değerlendirme ve Kalite Güvencesi Durum Raporu. [Online]https://yokak.gov.tr/Common/Docs/Site_Activity_Reports/20182019DurumRaporuv3.p df [Erişim Tarihi: 30.05 .2020$]$. 